IZA DP No. 7547

"Romanticizing Penniless Entrepreneurs?" The Relationship between Start-Ups and Human Wellbeing across Countries

Wim Naudé

José Ernesto Amorós

Oscar Cristi

August 2013 


\title{
"Romanticizing Penniless Entrepreneurs?" The Relationship between Start-Ups and Human Wellbeing across Countries
}

\author{
Wim Naudé \\ MsM, MGSoG, University of Maastricht, \\ UNU-MERIT and IZA \\ José Ernesto Amorós \\ Universidad del Desarrollo \\ Oscar Cristi \\ Universidad del Desarrollo
}

Discussion Paper No. 7547

August 2013

\author{
IZA \\ P.O. Box 7240 \\ 53072 Bonn \\ Germany \\ Phone: +49-228-3894-0 \\ Fax: +49-228-3894-180 \\ E-mail: iza@iza.org
}

\begin{abstract}
Any opinions expressed here are those of the author(s) and not those of IZA. Research published in this series may include views on policy, but the institute itself takes no institutional policy positions. The IZA research network is committed to the IZA Guiding Principles of Research Integrity.

The Institute for the Study of Labor (IZA) in Bonn is a local and virtual international research center and a place of communication between science, politics and business. IZA is an independent nonprofit organization supported by Deutsche Post Foundation. The center is associated with the University of Bonn and offers a stimulating research environment through its international network, workshops and conferences, data service, project support, research visits and doctoral program. IZA engages in (i) original and internationally competitive research in all fields of labor economics, (ii) development of policy concepts, and (iii) dissemination of research results and concepts to the interested public.
\end{abstract}

IZA Discussion Papers often represent preliminary work and are circulated to encourage discussion. Citation of such a paper should account for its provisional character. A revised version may be available directly from the author. 


\section{ABSTRACT \\ "Romanticizing Penniless Entrepreneurs?" The Relationship between Start-Ups and Human Wellbeing across Countries}

We study the effect of entrepreneurship and its allocation between necessity and opportunity entrepreneurship on three indicators of countries' wellbeing: monetary wellbeing, nonmonetary wellbeing and our own indicator of a country's ability to translate economic growth into non-monetary wellbeing. We take into consideration that there is a feedback effect from monetary and non-monetary wellbeing to entrepreneurial allocation. Using data from the Global Entrepreneurship Monitor we establish that opportunity entrepreneurship may contribute towards national wellbeing and that better wellbeing in turn may stimulate opportunity entrepreneurship. Hence, entrepreneurship may contribute towards countries' wellbeing in a broad sense, and countries with higher levels of wellbeing may contribute towards opportunity entrepreneurship.

JEL Classification: $\quad$ I31, M13, O50

Keywords: entrepreneurship, wellbeing, development, Global Entrepreneurship Monitor

Corresponding author:

Wim Naudé

Maastricht School of Management

P.O. Box 616

6200 MD Maastricht

The Netherlands

E-mail: naude@msm.nl 


\section{"Romanticizing Penniless Entrepreneurs?" The Relationship between Start-Ups and Human Wellbeing across Countries}

\section{Introduction}

Whether policies can improve entrepreneurship in developing countries, and whether more and better entrepreneurship will lead to better development outcomes have long been subject to controversy (Leff, 1979; Naudé, 2010a;b;c). At the basis of this controversy are divergent views with respect to the nature of entrepreneurship in developing countries. Here, the vast majority of entrepreneurs are active in micro and small enterprises (MSEs) with a significant proportion of these in the informal sector (Gollin, 2008; Maloney, 2004; Naudé, et al., 2008; Naudé and Gries, 2010; Nichter and Goldmark, 2009). Many scholars consider these as being founded out of necessity (for survival) due to failures in formal labour markets, and conclude that such entrepreneurs make little contribution to poverty alleviation and growth. Hence Banerjee and Duflo (2007, p. 162) warn that "it is important not to romanticize these penniless entrepreneurs". Others have also been dismissive of developing country entrepreneurship and thus of support to MSEs. Schramm (2004, p. 105) for example describes MSE support programmes as involving "cottage industries that add little to the economy in terms of productivity or growth" and Baumol, Litan, and Schramm (2007, p. 3) seems to reject any notion of MSEs as growth engines, stating that "if economic growth is the object of interest, then it is the innovative entrepreneur who matters".

On the other hand many consider MSEs, including informal and "survivalist" entrepreneurs as important for poverty alleviation and for growth. De Soto (1989) highlights the importance of the informal sectors in a weak institutional environment. Maloney (2004, p. 1159) for example argues that "we should think of the informal sector as the unregulated, developing country analogue of the voluntary entrepreneurial small firm sector found in advanced countries, rather than a residual comprised of disadvantaged workers rationed out of good jobs". Nichter and Goldmark (2009, p. 1453) reports evidence from a survey of 28,000 MSEs in Africa and Latin America where employment growth in the sector averaged almost 17 per cent per year. Bargain and Kwenda (2010) mention that earnings in the self-employment sector are often 
better than in the formal wage sector in many developing countries, and highlights Mexico as an example. In China, the rapid rise in the number of small, private entrepreneurs by more than 30 million over the period 1988 to 1995 has been identified as an important contributor to rapid growth and declining poverty (Mohapatra, Rozelle \& Goodhue, 2007, p. 163) and to exports (Naudé and Rossouw, 2010). Voeten, Haan and de Groot (2008) emphasises the innovativeness of MSEs in developing countries ${ }^{1}$, while many scholars have noted innovative behaviour and rapid adoptions of new innovations by small-scale entrepreneurs in developing countries $^{2}$. And with the majority of MSEs in developing countries being owned by women, their positive contribution to female empowerment and on the health and welfare of households of women entrepreneurs have been noted ${ }^{3}$ (Kevane and Wydick, 2001; Minniti and Naudé, 2010). More recently Amorós and Cristi (2011) and Naudé et al. (2013) studied the relationship between entrepreneurship and income poverty (monetary wellbeing) establishing that entrepreneurship has a positive effect on poverty reduction and that this effect is relatively higher in developing countries.

We do not aim to necessarily settle this controversy here. Rather we wish to add two fresh perspectives to the debate that we hope will contribute to a greater convergence of views on the role and importance of entrepreneurship in developing countries, and to the refinement of entrepreneurship policies. These perspectives relate first to the concept of development, and the second to the perceived instrumental nature of entrepreneurship. We believe that differences in how these are understood contribute to the different views outlined. Many studies on the topic tend to take a restricted view of development - in entrepreneurship studies it is almost exclusively associated with economic growth, productivity growth, per

1. Voeten et al. (2009:2) presents empirical evidence showing that 'in northern Vietnam, several clusters of small producers engaged in traditional crafts have introduced new technologies, new products and applied new business practices in recent years, expanding their sales on domestic and international markets.'

2. Feder, Just and Silberman (1985) report various studies that have found a very rapid adoption of high yield varieties of grains by developing country small farmers after the Green Revolution.

3 As Maloney (2004, p. 1162) implies, a substantial proportion of people in the informal and MSE sector in developing countries may be there not out of necessity, but because of choice, stating that "the disproportionate representation of women of informal self-employment may also again be found in certain desirable characteristics of the sector, particularly flexibility". 
capita income and/or employment growth (Nyström, 2008). Because these studies find mixed evidence of a strong impact of entrepreneurship on growth, and fail to show that 'necessity' entrepreneurship or self-employment matter for growth or per capita income, the conclusion is often that necessity/informal entrepreneurship and/or self-employment is not vital for economic development in developing countries. Little is said about the relationship between entrepreneurship and broader indicators of human wellbeing. It is seldom considered that entrepreneurship may be a goal in itself, or contribute to non-monetary wellbeing (Gries and Naudé, 2011).

Our position is hence that development is a multi-dimensional concept, and that the interest ought to be not only on the impact of entrepreneurship on income poverty, but also on nonmonetary human wellbeing. In the next section, following the theoretical formalisation of entrepreneurship as a human functioning by Gries and Naudé (2011) we derive a number of implications and hypotheses, which we subject in the remainder of the paper to empirical analysis. We use data from the Global Entrepreneurship Monitor (GEM) covering the period 2001 to 2010 to determine the relationship between entrepreneurship and monetary and nonmonetary wellbeing measures. By considering causality, we aim to investigate the extent to which improvements in monetary and non-monetary wellbeing can contribute to entrepreneurship, and hence whether or not the instrumental view of entrepreneurship is restrictive.

\section{Development as Human Development}

Just over twenty years ago the Human Development Index (HDI) was launched by the United Nations. This index aimed to provide a single measure to capture the fact that human development is a multidimensional concept, and that it cannot be reduced to monetary measures such as GDP or a poverty line. Therefore, the HDI includes indicators of literacy and life expectancy in addition to per capita income. While there are many criticisms of the HDI (see e.g. Naudé et al., 2009) and it is still agreed that it does not satisfactorily capture the complexity of human wellbeing, it did mark an important shift in global views on human development. Importantly in this regard, it reflected the growing acceptance of Amartya Sen, Martha 
Nussbaum and others' arguments that human development should be about broadening people's capabilities.

In the capabilities approach (CA), as this came to be known, human development is about people having "the freedoms (capabilities) to lead the kind of lives they want to lead, to do what they want to do and be the person they want to be. Once they effectively have these freedoms, "they can choose to act on those freedoms in line with their own ideas of the kind of life they want to live" (Robeyns, 2003, p. 7). In this light human development has been defined "as a process of enlarging people's choices" (UNDP, 1996, p. 49). These choices, or capability set (Q), can be written as $Q=\{f(g(x))\}$, which indicates that capabilities consists of various functionings $f($.$) , where the extent of functionings depend on the resource vector (g(x))$. The term functionings is central in the CA, and refers to "valuable activities and states that make up people's well-being" (Alkire, 2005, p. 1) and includes "working, resting, being literate, being healthy, being part of a community, being respected" (Robeyns, 2003, p. 6). Gries and Naudé (2011) argue that being entrepreneurial is also a functioning, as it can be valued in itself (more discussion below). The function $f$ will determine the extent to which resources or abilities can be turned into functionings - including functionings which improves a person or even country's overall improvement to multidimensional poverty. Here, since we will be using data on entrepreneurship on a country level, we will consider the functionings that is related to social development. For our purposes the function $f$, and the link it creates between entrepreneurship and social development, is important for two reasons:

First, because entrepreneurship is, apart from being a process, also a resource, the extent to which it will allow human functionings in other areas also depends on the function $f$. In some societies, a particular level of entrepreneurial capital may be much more efficiently translated into human functionings. How and why this is so, are however neglected questions. As we pointed out in the introduction until now the interest has been mainly in how entrepreneurship, as resource, facilitates economic growth. In the remainder of the paper we will be concerned to establish the extent to which entrepreneurship contributes to and 
facilitates human functionings - for instance in whether it improves non-monetary dimensions of wellbeing.

Second, if being entrepreneurial is to be a functioning, then resources and abilities must be available, and these must be translated into the outcome of being entrepreneurial (and achieved functioning). Across the world it is noticeable that, irrespective of how we measure the act of being entrepreneurial (whether as self-employment, business ownership, start-up activities or innovation) there are significant variations in the available of resources and abilities, as well as in the effectiveness with which resources and abilities are translated into entrepreneurial outcomes. In this paper our main interest is not in the factors determining this effectiveness, but rather in the implication of entrepreneurship like an end in itself, because entrepreneurial activities can be a human functioning. This would suggest that resources and other functionings, such as those that result from human development, will be driving entrepreneurship. In an environment characterized by high development, more people may be able to choose to be entrepreneurial. Hence in the remainder of the paper we will also be concerned to investigate the direction of causality between entrepreneurship and human development

\section{Entrepreneurship and human development}

What is the role of entrepreneurship in economic growth and human development? Although Adam Smith "detested" businessmen (Lewis 1988: 35) the creation and growth of business firms is widely seen to be necessary for economic growth and human development. The former has been explicit in economics for at least a century, following the Schumpeter's work "The Theory of Economic Development" (1912). The potential importance of entrepreneurship for economic growth and human development flows is implied from the central functions ascribed to the entrepreneur. These include innovation (Schumpeter, 1912), the reallocation of production factors from less productive to more productive uses (Ács and Storey, 2004; Audretsch and Keilbach, 2003), the provision of gap-filling and input-completing functions (Leibenstein, 1968), providing incentives for investments in human capital formation (Kwon \& Arenius, 2010), a cost-discovery function (Hausmann and Rodrik, 2003) and improvement of the 
general business and governance environment in a country through "institutional entrepreneurship" (Li et al., 2006).

These "growth and development" functions can benefit growth and development on both a micro and macro level. On a micro-level, it can contribute to better firm efficiency, more opportunities for new firm establishment, growth in employment, higher and more stable and diversified household incomes, higher tax revenue for governments, and improvements in governance. On a macro-level, these micro-level achievements could result in greater economic resilience and better aggregate outcomes as measured in terms of competitiveness, peace and stability, and political freedoms. Hence entrepreneurs can be argued to be necessary for expanding societies' freedoms and choices including better health and education outcomes. Where these lack the supply of entrepreneurship is often diagnosed to be inadequate (lyugun and Rodrik, 2004; Schulpen and Gibbon, 2002).

But the performance of these key entrepreneurial functions will not automatically lead to either growth or human development. And even if it does lead to economic growth, economic growth does not automatically imply improved human development. The latter will require growth to be sustainable, shared, and improving people's positive freedoms. Thus, innovation may bring benefits, both for growth and human wellbeing (for example through the development of new medicines) but can also retard growth and limit human development (e.g. development of weapons) or just be ineffectual for broader development. Likewise, entrepreneurs do not automatically reallocate scarce resources towards their most productive uses and rather they do so towards its most profitable uses, which as the 2008 global financial crisis has shown, can involve the creation of asset price bubbles rather than productive investment. And very often, high growth is accompanied by growing income and wealth inequality, environmental damage, corruption and conflict, with little impact on better governance and on expanding people's freedoms.

Hence, a priori the relationship between the total supply of entrepreneurs on economic growth and human development is ambiguous. This has been stressed by Baumol (1990) who argued that the allocation of entrepreneurship matters more than its supply. It is what entrepreneurs 
do what matters. Accordingly, a growingly literature has examined various types of entrepreneurship and its measurement. For example the GEM project makes a distinction between necessity (NEC) and opportunity entrepreneurship (OPP), where the former is start-up activity which is the result, according to the entrepreneur of a lack of any better opportunities in the labor market. Whereas empirical evidence has been mixed on the impact of total start-up activities on economic performance, a number of studies do find a positive impact of productive opportunity-type entrepreneurship, thus tending to confirm Baumol's (1990) thesis that the type or allocation of entrepreneurship may matter more ${ }^{4}$.

We are also however, interested in the general relationship between entrepreneurship and human development. This is because the supply and the allocation of entrepreneurship, which will ultimately matter for development, is itself influenced by human development. Thus a growing body of research notes the importance of governance, of freedom, of human capital often subsumed under the heading 'institutions'- on entrepreneurship. More recently the existence of this two-way relationship has been implicit in a growing awareness that the relationship between entrepreneurship and economic growth differs across the level of a country's development (Ács and Szerb, 2009; Ács and Naudé, 2013). This suggests that a priori there could be a negative relationship between changes in the supply of entrepreneurship: at low levels of development, a higher total supply of entrepreneurship is needed to fulfill gapping-filling, input-completing and cost-discovery functions, which will mean that the rate of new firm entry (new start-ups) should be high, whereas at higher levels of development, smaller marginal changes in the stock of entrepreneurship is needed to push out the production possibilities frontier.

Based on this discussion we can now forward three hypotheses.

\footnotetext{
${ }^{4}$ Opportunity-based entrepreneurs could be a proxy for Baumol's productive entrepreneurial activities, but some "business opportunities" can incorporate any type of entrepreneurial activity, including self-employment, and this can involve low-growth or no-growth entrepreneurship.
} 


\section{Hypotheses and Research Methodology}

\subsection{Hypotheses}

Based on the discussion so far, we can state that there is bi-directional causality between monetary (strictly economic) and non-monetary measures of wellbeing and entrepreneurship allocation. The sign and strength of the causality depends on the motivation for entrepreneurship, whether it takes place to utilise an opportunity or out of necessity. Moreover there is also a bi-directional causality between the motivation for entrepreneurship and monetary and non-monetary measures of wellbeing.

This suggests the following hypotheses:

Hypothesis 1: Monetary and non-monetary human wellbeing, as well as countries' ability to increase non-monetary wellbeing when GDP expands, depend on its level of entrepreneurship.

Hypothesis 2: Opportunity entrepreneurship will contribute to monetary and nonmonetary human wellbeing, as well as to better ability of society to increase nonmonetary wellbeing, whereas necessity entrepreneurship will not.

Discussion: When people are forced into entrepreneurship, they may be unable to improve dimensions of their non-monetary wellbeing such as obtaining education or maintaining or improving health. Non-monetary dimensions of wellbeing would therefore suffer in the absence of human agency. On the other hand, improving human capabilities by adding human functionings such as education and health will contribute to facilitate people becoming opportunity entrepreneurs - which will in turn have a positive impact also on monetary wellbeing (GDP).

Improvements in human capabilities are often the outcome of greater public investment that accompanies growth in GDP (although the relationship is not always strong or linear).

Hypothesis 3: Higher levels of non-monetary and monetary wellbeing in a country are associated with higher opportunity (OPP) relative to necessity (NEC) entrepreneurship. 
Discussion: We expect that both monetary and non-monetary wellbeing indicators will influence the rate of start-ups and its typologies (opportunity or necessity-based). Thus, at lower levels of wellbeing the rate of necessity entrepreneurship will be high, while at higher levels of wellbeing, opportunity entrepreneurship will be more predominant than necessity entrepreneurship.

\subsection{Data and Variables}

Entrepreneurship: Our data is obtained from the GEM project database, which provides harmonized, internationally comparable data on entrepreneurial activity at country level. By the end of 2010, 84 different economies have participated in GEM. Among them, 54 countries could be classified as developing economies (low and middle-income countries). GEM project (Reynolds et al., 2005) estimates the percentage of adult population (people between 18 and 64 years old) that is actively involved in starting a new venture like a nascent entrepreneur or as an owner-manager of a new business with no more than 42 month. This rate is referred to as the Early-stage Entrepreneurial Activity Index (TEA). TEA rate can be disaggregated accordingly to the main two motives that entrepreneurs "follow": The first one includes opportunity-based entrepreneurs (OPP) who have taken actions to create a new venture pursuing perceived business opportunities, while the second category corresponds to the necessity-based entrepreneurs (NEC) who become involved in entrepreneurial activities because they have no other way to earn a living. Empirical evidence shows that NEC rates are higher in low-middle income countries (Ács and Amorós, 2008; Amorós and Cristi, 2011; Bosma, Ács, at al., 2009; Wennekers, van Stel, Thurik and Reynolds, 2005). Although, GEM data is available from 2000 we used data from 2001 to 2010. This is because on year 2000 GEM project does not include data on OPP and NEC.

Development Indicators: we use the Human Development Index (HDI) to build proxies for nonmonetary wellbeing and a country's ability to translate economic growth into non-monetary wellbeing (this latter is our own index of wellbeing - we explain more below). HDI is calculated by the United Nations Development Programme and publishes this measure in the Human 
Development Reports ${ }^{5}$. The HDI is a composite index that measures average achievement in a country by evaluating three dimensions of human development: life expectancy at birth (long and healthy life), adult literacy rate (education and knowledge) and GDP per capita in purchasing power parities (decent standard of living). The HDI takes values from 0 to 1 where 1 stands for the highest attainment. The dimensions of the HDI reflect major concerns in the study of development and poverty reduction (Misturelli and Heffernan, 2008).

Our proxy for non-monetary wellbeing is the per-country simple average of the life expectancy and literacy rates used in the calculation of HDI. We label this variable as the life-literacy wellbeing index (LEWI) and it has values from 0 to 1, where 1 indicates the highest levels of life expectancy and literacy rates.

Our proxy (or index) for country's ability to translate economic growth into non-monetary wellbeing is based on the difference among countries to reach higher levels of HDI for a given GDP per capita. We argue here, following Naudé et al. (2009) that this is an important, but neglected dimension of wellbeing - because growth in monetary wellbeing does not always improve non-monetary wellbeing, but do some in some cases - so that the concepts are interrelated. From an empirical point of view the ability of countries to translate monetary into non-monetary gains can be measured at country level by calculating the deviation on its HDI from the predicted value for HDI given its GDP per capita. We label this measure the HDI Intervention Index (HDIII) because it indicates whether countries may need more than just increases in per capita incomes to improve human wellbeing. The measure follows directly from the preceding observations and it is obtained by estimating the following equation for HDI:

$$
H D I_{i t}=\chi_{0}+\chi_{1} g\left(G D P_{i t}\right)+\varepsilon_{i t}
$$

Where, $\chi_{0}$ is an intercept term, $\chi_{1}$ is a slope coefficient, $g(G D P)$ is some transformation of per capita income and $\varepsilon$ is an error term. The transformation of income is based on the recognition that the relationship between $\mathrm{HDI}$ and per capita income may be non-linear. We use the Box-

5. For more information on the methodology of HDI, see the most recent Human Development Report 2011 technical notes (UNDP, 2011, p.167). 
Cox transformation to allow the data determine what functional form is more appropriate. This Box -Cox transformation is:

$$
g\left(G D P_{i t}\right)=\frac{G D P_{i t}^{\lambda}-1}{\lambda}
$$

where $\lambda$ is an unknown parameter.

Then we replace (2) in (1) and we obtain the maximum likelihood estimates for $\chi_{0} \chi_{1}$, and $\lambda$ ( $\hat{\chi}_{0}, \hat{\chi}_{1}$ and $\left.\hat{\lambda}\right)$. Results for these estimates are presented in Table 1.

\section{"Insert Table 1 Here"}

Results indicate that $\chi_{1}$ is statistically significant at $5 \%$ and its point estimation is -0.07 . Moreover, transformed GDP is statistically significant and as it increases the higher is the value of the HDI.

Once we get the parameters estimates we compute the predicted value of HDI given a value of GDP (also is the conditional expected value of HDI given GDP) as:

$$
E\left[H D I_{i t} / G D P_{i t}\right]=\hat{\chi}_{0}+\hat{\chi}_{1} g\left(G D P_{i t}\right)
$$

Our HDIII is then obtained as the difference between that predicted value and the sample value for HDI:

$$
H D I I=H D I_{i t}-E\left[H D I_{i t} / G D P_{i t}\right] .
$$

When for a specific country $H D I I I>0$ then $H D I_{i t}>E\left[H D I_{i t} / G D P_{i t}\right]$ which implies that this country has a value of HDI greater than the expected one given its GDP. Thus when we compare countries we say that those with positive values of HDIII have greater ability to translate economic growth into no-monetary wellbeing that those with negative HDIII. Hence, the country with the highest positive (most negative) value for HDIII is the one that translates economic growth into non-monetary wellbeing the best (worst). 
To capture the economic effects and qualifying the economic environment that shapes entrepreneurial activities (Wennekers et al., 2005) we include GDP per capita adjusted by purchasing power parity (PPP) in international US dollars. Data is sourced from the IMF's World Economic Outlook Databases.

Annex shows the list of countries that have been involved in GEM project 2001-2010.

\subsection{Model and estimation procedures}

To model the relationship among entrepreneurship, countries' non-monetary wellbeing, monetary wellbeing, and its ability to translate economic growth into non-monetary wellbeing, we propose the following set of equations:

$$
\begin{gathered}
\text { HDIII }_{i t}=\phi_{0}+\phi_{1} \mathrm{TEA}_{i t}+\phi_{2} T E A_{i t} \times\left(\frac{O P P_{i t}}{N E C_{i t}}\right)+\phi_{3} L E W I+\phi_{4} L E W I_{i t} \times\left(\frac{O P P_{i t}}{N E C_{i t}}\right)+\mu_{i t} \\
L E W I_{i t}=\theta_{0}+\theta_{1} T A_{i t}+\theta_{2} T E A_{i t}^{2}+\theta_{3} T E A_{i t} \times\left(\frac{O P P_{i t}}{N E C_{i t}}\right)+\pi_{i t} \\
G D P_{i t}=\delta_{0}+\delta_{1} T E A_{i t}+\delta_{2} T E A_{i t}^{2}+\delta_{3} T E A_{i t} \times\left(\frac{O P P_{i t}}{N E C_{i t}}\right)+v_{i t} \\
\left(\frac{O P P_{i t}}{N E C_{i t}}\right)=\beta_{0}+\beta_{1} G D P_{i t}+\beta_{2} G D P_{i t}^{2}+\beta_{3} L E W I_{i t}+\beta_{4} L E W I_{i t}^{2}+\omega_{i t}
\end{gathered}
$$

Equations (5), (6) and (7) follow from hypothesis 1 and 2. Equation (8) follows from hypothesis 3. The vectors of parameters $\phi, \theta, \delta$ and $\beta$ are unknown and the vectors $\pi, v, \mu$ and $\omega$ represent stochastic error terms.

Equations (5) (6) and (7) include the term $T E A_{i t} \times\left(\frac{O P P_{i t}}{N E C_{i t}}\right)$ to analyze whether or not the contribution of TEA on monetary and non-monetary wellbeing as well as on the country's ability to translate increases in per capita GDP into non-monetary wellbeing, depends on the allocation of TEA between OPP and NEC. Accordingly to our hypothesis 2, we expect a positive 
sign for parameters $\phi_{2}, \theta_{3}$ and $\delta_{3}$ which would confirm that the contribution of TEA is positively related to opportunity entrepreneurship.

Equation (5) also includes LEWI to account for possible effects of life expectancy at birth and adult literacy rate on the on country's ability to translate increases in per capita GDP into nonmonetary wellbeing. Moreover, we added the variable LEWI x OPP/NEC to allow for the possibility that the effect of LEWI upon HDIII depends on the allocation of TEA between OPP and NEC.

Equation (8) follows from hypothesis 3 that indicates that as monetary and non-monetary wellbeing increase, opportunity entrepreneurship (OPP) will be more predominant than necessity entrepreneurship (NEC).

Equations (6) and (7) include the square value of TEA, whereas equation (8) includes the squared value of GDP and LEWI. This allow for no linear relationships between dependent variables and the regressors.

We implement our estimations on the observations pooled across countries and years because our panel data is strongly unbalanced: more than 45 per cent of the countries have 4 or less observations. By doing this we add to the error term of each equation the unobserved country characteristics, which may be constant over the period under study, and this create a composite error term. This may cause correlation between the regressors and the error term of each equation, because some of the regressors may be correlated with the unobserved effect that is included in the composite error term.

Moreover, endogeneity problems of regressors may also arise because the already mentioned possible existence of bi-directional causality between monetary and non-monetary measures of wellbeing and entrepreneurship.

To overcome these problems between regressors and the error terms we use an instrumental variable approach that use instruments for the regressors that are correlated with the error (Wooldridge, 2002, Section 10.1). 
Even if the above approach addresses the endogeneity problem, the composite error term may be serially correlated and may have heterogeneous variance due to the presence of the unobserved effect. Therefore, we implement the instrumental variable approach using the generalized method of moments (GMM) which is more efficient than the simple Instrumental Variable (IV) estimator when heteroskedasticity is present (Baum, Schaffer and Stillman, 2003). We implement the GMM continuously updated estimator (CUE) of Hansen, Heaton and Yaron $(1996)^{6}$. Moreover, we combine this procedure with the "sandwich estimate" of the covariance matrix (known as the robust covariance matrix estimator) ${ }^{7}$ and the error terms are allowed to be correlated within countries (clustering). This method produces consistent and efficient estimates and statistics robust to arbitrary heteroskedasticity and intragroup correlation such as serial correlation ${ }^{8}$.

To implement the GMM method we use a set of Institutional Variables as instruments. These variables are related to the governance and general business environment in each country. One of these variables comes from the World Bank's Worldwide Governance Indicators (WGI). We utilize from WGI the variable Government Effectiveness (Gef) defined in exact terms according to Kaufmann et al. (2008, pp. 7-8) as measuring perceptions of the quality of public services, the quality of the civil service and the degree of its independence from political pressures. In the WGI this variable ranges between -2.5 and 2.5, with the higher scores corresponding to better outcomes. More effective governments may result in an environment where it is cheaper to start a new business. More effective governments may also reduce the need for people to enter the informal economy and so reduce necessity entrepreneurship.

The other variables that we use were taken from the annual Index of Economic Freedom produced by The Wall Street Journal and The Heritage Foundation that tracks economic freedom around the world. The Index covers 10 freedoms -from property rights to

\footnotetext{
6 In Monte-Carlo experiments this method demonstrated a better performance than the traditional two-step GMM (Hansen et al., 1996).

7 Eicker (1967) and Huber (1967) introduced these "sandwich estimators".

${ }^{8}$ We accomplish this estimation procedure in STATA with ivreg2 and the cue, robust and cluster options.
} 
entrepreneurship. Here we use two of the components of the total Economic Freedom Index: Property Rights (Pr) and Government Size (Gs). Property rights have a strong relationship with the develop of specific entrepreneurial activities: "Secure property rights give citizens the confidence to undertake commercial activities, save their income, and make long-term plans because they know that their income and savings are safe from expropriation or theft. The protection of private property requires an effective and honest judicial system that is available to all, equally and without discrimination" (Miller \& Holmes, 2009, pp. 14-15). Government size may be taken as an indicator of the coverage and extent of government provision of basic services, such as education and health. It can also be interpreted as an indicator of the tax and regulatory burden on entrepreneurs. The Index methodology uses a scale from 0 to 100, where 100 indicate highest degrees of freedom.

Unfortunately, there are not data on Property Rights and Government Size for 2001. This implies that part of our empirical analysis cover the period 2002 to $2010^{9}$.

Table 2 shows the descriptive statistics and correlation matrix of the full set of variables used in the estimation process.

\section{"Insert Table 2 Here"}

\section{Estimation Results}

As we previously indicated, in all our equations we use Government Effectiveness (Gef), Property Rights (Pr) and Government Size (Gs), their squares and cross products as instruments.

We first test for heteroskedasticity in each equation using the Pagan and Hall (1983) test. Under the null hypothesis of homoskedasticity the Pagan-Hall test is distributed as a chi-squared. We implement this test estimating each equation with IV. Results from this test will indicate whether we use IV or GMM. In cases of rejecting homoskedasticity we test the exogeneity of the regressor with the GMM distance statistics ${ }^{10}$ (" $\mathrm{C}$ " test) which is appropriate in the context

\footnotetext{
${ }^{9}$ As we mentioned before on year 2000 the GEM project estimated TEA but not OPP nor NEC

10 More details about this test can be found in Wooldridge (2002, Section 8.5) and in Baum et al. (2003).
} 
of efficient GMM estimation (Baum et al., 2003). This statistic is distributed chi-squared under the null hypothesis that the specified orthogonality conditions are satisfied, with degrees of freedom equal to the number of these conditions ${ }^{11}$.

Results of heteroskedasticity tests indicate that we should reject the hypothesis of homokedasticity at 1 per cent in the equation for HDIII, at 10 per cent in the equation for LEWII, at 5 per cent in the equation for GDP and at 1 per cent in the equation for the ratio between OPP and NEC. These results suggest the appropriateness of using our GMM estimator.

The C-test of exogeneity for the regressors in the equation for HDIII indicate that we can reject the hypothesis that TEA, TEA $x$ OPP/NEC and LEWI $x$ are jointly exogenous. In the equation for GDP and for LEWI we do reject that TEA and TEA x OPP/NEC are jointly exogenous. In equation for the ratio between OPP and NEC we can reject the hypothesis that GDP and LEWI are jointly exogenous. These results further suggest the appropriateness of the GMM estimation.

Finally, in each equation we verified the rank condition and we tested for the orthogonality of the included and excluded instruments, and whether or not the excluded instrument are correctly exclude in each equation. For the latter we use the Hansen's (1982) J-statistics that is a test of over-identifying restrictions. The joint null hypothesis is that the instruments are valid instruments, i.e., uncorrelated with the error term, and that the excluded instruments are correctly excluded from the estimated equation. This Hansen's J-statistic is consistent in the presence of heteroskedasticity and autocorrelation. All these test support the selection that we made of included and excluded instruments in each equation.

Table 3 shows the estimates for each equation using GMM continuously updated estimator (CUE) combined with the "sandwich estimate" of the covariance matrix and clustered errors.

\section{"Insert Table 3 Here"}

\footnotetext{
${ }^{11}$ This test is implemented in STATA with the orthog option of ivreg2.
} 
Results for the equation of HDIII indicates that as a country's opportunity entrepreneurship rate, level of life expectancy at birth, and adult literacy rate (LEWI) improves, the better a country seem to be able to transform GDP gains into non-monetary wellbeing. This result is consistent with our hypothesis 1 . Also, the ratio between OPP and NEC reduce the impact of TEA upon HDIII whereas that ratio increases the impact of LEWI on HDIII. This result partially supports our hypothesis 2 .

Results for the equation of the composite index of level of life expectancy at birth and adult literacy rate (LEWI) indicate that there exists an inverse relationship between TEA and LEWI up until a certain threshold, after which increases in TEA are associated with a higher level of LEWI i.e. a " $U$ " shape relationship. This result is consistent with hypothesis 1 . Moreover, the coefficient on the variable TEA $x$ OPP/NEC has a positive sign, which indicates that the effect of TEA upon LEWI is positively associated with the ratio between OPP and NEC. This result supports hypothesis 2 .

Results for the equation of GDP suggest that entrepreneurial activity improves a country's GDP but only when OPP is several times higher than NEC (our point estimation indicates that OPP has to be at least 2.4 times greater than NEC). These results support hypotheses 1 and 2 . In this equation the squared value of TEA is not statically significant.

Finally, estimates of the equation for the ratio between OPP and NEC show that GDP is statistically significant whereas LEWI is not. Moreover, GDP is associated with increases in opportunity relative to necessity entrepreneurship. This provides partial support to hypothesis 3. We have to point out that this may be due to the strong correlation between GDP and LEWI (sample correlation is 0.74). As a consequence the standard error of the estimator for LEWI tends to be large and the test of the hypothesis that the coefficient is equal to zero leads to a failure to reject the null hypothesis. In fact, estimation of equation for OPP/NEC including only LEWI and its squared value illustrates that LEWI affects the OPP/NEC ratio. More specifically, there exists an inverse relationship between OPP/NEC and LEWI until some threshold, after which increases in LEWI are associated with higher level of OPP/NEC. This finding supports hypothesis 3. 


\section{Concluding Remarks}

Following the capability approach to human wellbeing and poverty, we started out by arguing that if the relationship between entrepreneurship and development is to be correctly understood, empirical analyses need to be broadened to focus also on non-monetary measures of development. In this paper we did this by considering the relationship between measures of start-up entrepreneurship that allows for various types of entrepreneurship, and measures of non-monetary wellbeing. Our empirical findings could not reject our two hypotheses, suggesting that the empirical evidence is supportive of the capabilities approach to human development, wherein opportunity entrepreneurship (entrepreneurship as a functioning) contributes to human wellbeing, and where high rates of necessity entrepreneurship suggest a lack of agency.

The policy implications are that poor countries can improve their human wellbeing (both monetary and non-monetary) by facilitating improvements in the allocation of entrepreneurship from necessity to opportunity entrepreneurship. To the extent that economic growth and development could create opportunities, this would imply that at early stages of development the causality could run from growth and development to entrepreneurship, rather than the other way around. To expect that 'penniless entrepreneurs' can be engines of development indeed seems to be somewhat of a romantic fantasy.

Two caveats need to be stressed. The first is that our data covers only a relative short time period and it is more than likely that the beneficial impacts of opportunity entrepreneurship on development outcomes (for which the theoretical and historical cases are strong) only operate on a much longer time horizon. Second, and related to the previous caveat, is the fact that we have only used entrepreneurship indicators measuring marginal changes in the stock of entrepreneurs (i.e. the partial flow). This will not account for the impact of the stock of entrepreneurship on development, and for variations in the stock of entrepreneurship over the course of a country's development. If, at earlier stages of development there is a mismatch between opportunities and the entrepreneurial stock, then the rate of new start-ups may possibly be too high at such stages. This would mean, as Gries and Naudé (2011) recently 
illustrated that policy efforts aimed to improve the search of entrepreneurs' efficiency (through for instance improvements in human capital/education) and the transaction costs in the economy (through institutional reform) would indeed be consistent with human development.

\section{Acknowledgements}

The authors would like to extend their thanks to the GEM Consortium and GEM Project Coordination. The usual disclaimer applies. Any remaining errors are our own.

\section{References}

Ács, Z.J., \& Amorós, J.E. (2008) Entrepreneurship and Competitiveness Dynamics in Latin America. Small Business Economics, 31(3), 305-322.

Ács, Z., and Storey, J.D. (2004). Special Issue: Entrepreneurship and Regional Development: Essays in Honour of David Keeble. Regional Studies, 38(8), 867-989.

Ács, Z. J., and Szerb, L. (2009). The Global Entrepreneurship Index (GEINDEX). Foundations and Trends in Entrepreneurship, 5(5), 341-435.

Ács, Z. J., and Naudé, W.A. (2013). 'Entrepreneurship, Stages of Development, and Industrialization' (In Szirmai, A., Naudé, W.A. and Alcorta, L. eds. Pathways to Industrialization in the $21^{\text {st }}$ Century. Oxford: Oxford University Press. Chapter 14).

Alkire, S. (2005). Capability and Functionings: Definition and Justification. Human Development and Capability Association Briefing Note, September.

Amorós, J.E., and Cristi, O. (2011). 'Poverty and Entrepreneurship in Developing countries', (In Minniti, M. ed. The Dynamics of Entrepreneurship: Evidence from Global Entrepreneurship Monitor Data Oxford: Oxford University Press. pp. 209-230).

Anokhin, S., and Schulze, W. S. (2008). Entrepreneurship, innovation, and corruption. Journal of Business Venturing, 24(5): 465-476.

Audretsch, D., and Keilbach, M. (2004). Entrepreneurship and Regional Growth: an Evolutionary Interpretation. Journal of Evolutionary Economics, 14(5), 605-616.

Banerjee, A.V., and Duflo, E. (2007). The Economic Lives of the Poor. Journal of Economic Perspectives, 21(1), 141-67. 
Bargain, O. and Kwenda, P. (2010). Is Informality Bad? Evidence from Brazil, Mexico and South Africa, IZA Discussion Paper No. 4711, Bonn: IZA.

Baum, C., Schaffer, M.E., and Stillman, S. (2007). Enhanced routines for instrumental variables/GMM estimation and testing. Boston College Working Papers in Economics 667.

Baum, C., Schaffer, M.E., and Stillman, S. (2003). Instrumental variables and GMM: Estimation and testing. The Stata Journal, 3(1), 1-31.

Baumol, W. J. (1990). Entrepreneurship: Productive, Unproductive and Destructive. Journal of Political Economy, 98(5), 893-921.

Baumol, W.J., Litan, R.E., and Schramm, C.J. (2007). Good Capitalism, Bad Capitalism and the Economics of Growth and Prosperity. New Haven, CT: Yale University Press.

Boettke, P., and Coyne, C. (2007). 'Entrepreneurial behavior and institutions' (In Minniti,M. ed. Entrepreneurship: The engine of growth, Vol. 1 Perspective Series. Westport, CT: Praeger Press-Greenwood Publishing Group. pp. 119-34).

Bosma, N., Acs, Z. Autio, E., Coduras, A., and Levie, J. (2009). Global Entrepreneurship Monitor, 2008 Executive Report. Wellesley, MA.: Babson College.

Briguglio, L., Cordina, G., Farrugia, N., and Vella, S. (2008). Economic Vulnerability and Resilience Concepts and Measurements. WIDER Research Paper RP2008/55, Helsinki: United Nations University,

Chen, S., and Ravallion, M. (2008). The Developing World Is Poorer Than We Thought, but No Less Successful in the Fight Against Poverty. Policy Research Working Paper 4703. Washington, DC: World Bank.

De Soto, H. (1989). The other path: The invisible revolution in the Third World. New York: Harper \& Row.

Eicker, F. (1967). Limit theorems for regressions with unequal and dependent errors. Proceedings of the Fifth Berkeley Symposium on Mathematical Statistics and Probability. Berkeley, CA: University of California Press, 1: 59-82.

Feder, G., Just, R.E., and Silberman, D. (1985). Adoption of Agricultural Innovations in Developing Countries, A Survey. Economic Development and Cultural Change, 33(2), 255298. 
Gastwirth, J. L. (1972). The Estimation of the Lorenz Curve and Gini Index. The Review of Economics and Statistics, 54(3), 306-16.

Gollin, D. (2008). Nobody's business but my own: Self-employment and small enterprise in economic development. Journal of Monetary Economics, 55(2), 219-233.

Green, William H. (1993). Econometric Analysis. New Jersey: Prentice Hall.

Gries, T., and Naudé, W.A. (2010). Entrepreneurship and Structural Economic Transformation, Small Business Economics Journal, 34(1), 13-29.

Hansen, L. P., Heaton, J., and Yaron, A. (1996). Journal of Business \& Economic Statistics, 14(3), 262-280.

Gries, T., and Naudé, W.A. (2011). 'Entrepreneurship and Human Development: A Capability Approach', Journal of Public Economics, 95(3), 216-224.

Hansen, L. (1982). Large sample properties of the generalized method of moments estimators. Econometrica, 50(4), 1029-1054.

Hausmann, R., and Rodrick, D. (2003). 'Economic Development as Self-Discovery', Journal of Development Economics, 72(2), 603-633.

Huber, P. J. (1967). The behavior of maximum likelihood estimates under non-standard conditions. Proceedings of the Fifth Berkeley Symposium on Mathematical Statistics and Probability, Berkeley: University of California Press, 1, 221-233.

Iyigun, M., and Rodrik, D. (2004). 'On the Efficacy of Reforms: Policy Tinkering, Institutional Change, and Entrepreneurship', NBER Working Papers 10455.

Kaufmann, D., Kraay, A. and Mastruzzi, M. (2008). Governance Matters VII: Aggregate and Individual Governance Indicators, 1996-2007, World Bank Policy Research Working Paper 4654, Washington, DC: World Bank.

Kevane, M., and Wydick, B. (2001). Social Norms and the Time Allocation of Women's Labor in Burkina Faso. Review of Development Economics, 5(1), 119-29.

Kwon, S., and Arenius, P. (2010). Nations of entrepreneurs: A social capital perspective. Journal of Business Venturing, 25(3), 315-330.

Leibenstein, H. (1968). Entrepreneurship and Development. American Economic Review, 58(2), 72-83. 
Leff, N. (1979). Entrepreneurship and Economic Development: The Problem Revisited. Journal of Economic Literature, 17(1), 46-64.

Lewis, W.A. (1988). 'The Roots of Development Theory' (In Chenery, H.B. and Srinivasan, T.N. eds. Handbook of Development Economics, volume 1. Elsevier.).

Li, D.D., Feng, J., and Jiang, H. (2005). Institutional Entrepreneurs. American Economic Review, 96(2), 358-362.

Maloney, W. F. (2004). Informality Revisited. World Development, 32(7), 1159-1178.

Miller, T. and Holmes, K.R. (2009). 2009 Index of Economic Freedom. Washington D.C, New York: The Heritage Foundation and Dow Jones \& Company, Inc.

Minniti, M. (2008). The Role of Government Policy on Entrepreneurial Activity: Productive, Unproductive, or Destructive? Entrepreneurship: Theory \& Practice, 32(5), 779-90.

Minniti, M., and Naudé, W.A. (2010). 'What do We Know About the Patterns and Determinants of Female Entrepreneurship Across Countries?', The European Journal of Development Research, 22(3): 277-293.

Misturelli, F., and C. Heffernan (2008). 'What is Poverty? A Diachronic Exploration of the Discourse on Poverty from the 1970s to the 2000s', European Journal of Development Research, 20(4): 666-684.

Mohapatra, S., Rozelle, S., and Goodhue, R. (2007). 'The Rise of Self-Employment in Rural China, Development or Distress?', World Development, 35(1), 163-81.

Naudé, W.A. (2010a). Entrepreneurship and Economic Development. Basingstoke: Palgrave Macmillan.

Naudé, W.A. (2010b). 'Entrepreneurship is not a binding constraint on growth and development in the poorest countries', World Development, 39(1): 33-44.

Naudé, W.A. (2010c). Entrepreneurship, Developing Countries and Development Economics, New Approaches and Insights. Small Business Economics, 34(1), 1-12.

Naudé, W. A., and Rossouw, S. (2010). 'Early International Entrepreneurship in China, Extent and Determinants', Journal of International Entrepreneurship, 8(1), 87-111. 
Naudé, W.A., Gries, T., Wood, E., ad Meintjes, A. (2008). 'Regional Determinants of Entrepreneurial Start-Ups in a Developing Country', Entrepreneurship and Regional Development, 20(2), 111-124.

Naudé, W.A., Santos-Paulino, A., and McGillivray, M. (2009). Vulnerability in Developing Countries. Tokyo: United Nations University Press.

Naudé, W.A., Amorós, E. and Cristi, O. (2013). 'Surfeiting the Appetite may Sicken: Entrepreneurship and the Happiness of Nations', Small Business Economics, early online.

Nichter, S., and Goldmark, L. (2009). Small Firm Growth in Developing Countries. World Development, 37(9), 1453-1464.

Pagan, A.R., and A.D. Hall (1983). Diagnostic Test as Residual Analysis. Econometric Reviews,2(2), 159-218.

Porter, M, Sachs, J., and McArthur, J. (2002). Executive summary: competitiveness and stages of economic development. In Porter, M, Sachs, J, Cornelius, P K, McArthur, J W and Schwab, K (Eds.), The Global Competitiveness Report 2001-2002 (pp. 16-25). New York: Oxford University Press.

Reynolds, P.D., Bosma, N., Autio, E., Hunt, S., Bono, N.D., Servais, I., Lopez-Garcia, P., and Chin, N. (2005). Global entrepreneurship monitor: data collection design and implementation 1998-2003. Small Business Economics, 24(3), 205-231.

Robeyns, I. (2003). The Capability Approach: An Interdisciplinary Introduction. Mimeo: Amsterdam School of Social Sciences, December.

Rostow, W.W. (1960). The Stages of Economic Growth; a Non-Communist Manifesto. Cambridge, UK: Cambridge University Press.

Schumpeter, J. A. (1912, reedit 1934). The Theory of Economic Development. Cambridge, MA: Harvard University Press.

Schramm, C.J. (2004). Building Entrepreneurial Economies, Foreign Affairs 83(4), 104-15.

Sharp, A., Register, C., and Grimes, P. (2003). Economics of Social Issues, 16th Edition. New York: McGraw-Hill/Irwin.

Schulpen, L., and Gibbon, P. (2002) Private Sector Development: Policies, Practices and Problems. World Development, 30(1), 1-15 
UNDP (1996). Human Development Report. New York: United Nations Development Programme.

UNDP (2011). Human Development Report 2011. New York: Palgrave Macmillan.

Voeten, J., de Haan, J., and de Groot, G. (2008, 30 October). Is that Innovation? Assessing Examples of Revitalized Economic Dynamics Among Clusters of Small Producers in Northern Vietnam, Paper presented at the UNU-WIDER and UNU-MERIT workshop on Innovation, Entrepreneurship and Economic Development, Maastricht, The Netherlands.

Wennekers, S., van Stel, A., Thurik, R., and Reynolds, P.D. (2005). Nascent entrepreneurship and the level of economic development. Small Business Economics, 24(3), 293-309.

Woolddridge, J.M. (2002). Econometric Analysis of Cross Section and Panel Data. Cambridge, MA: The MIT Press. 
Table 1: Estimates of the parameters of the Box-Cox transformation in equation of HDI

\begin{tabular}{lr}
\multicolumn{1}{c}{ Variable } & Estimates \\
\hline Lambda & $-0.07^{* *}$ \\
& $(0.03)$ \\
Transformed GDP & $0.2^{* * *}$ \\
Chi-squared value for test H0: $\chi_{1}=0$ & 1354 \\
Constant & -0.7 \\
Sigma & 0.04 \\
LR Chi squared & $1354^{* * *}$ \\
Number of observations & 704 \\
\hline Standard error between brackets. ${ }^{* * * * *}, *$ indicate statistically \\
significant at $1 \%, 5 \%$ and $10 \%$ respectively.
\end{tabular}


Table 2: Descriptive statistics and correlation for variables used in the estimation of the equations.

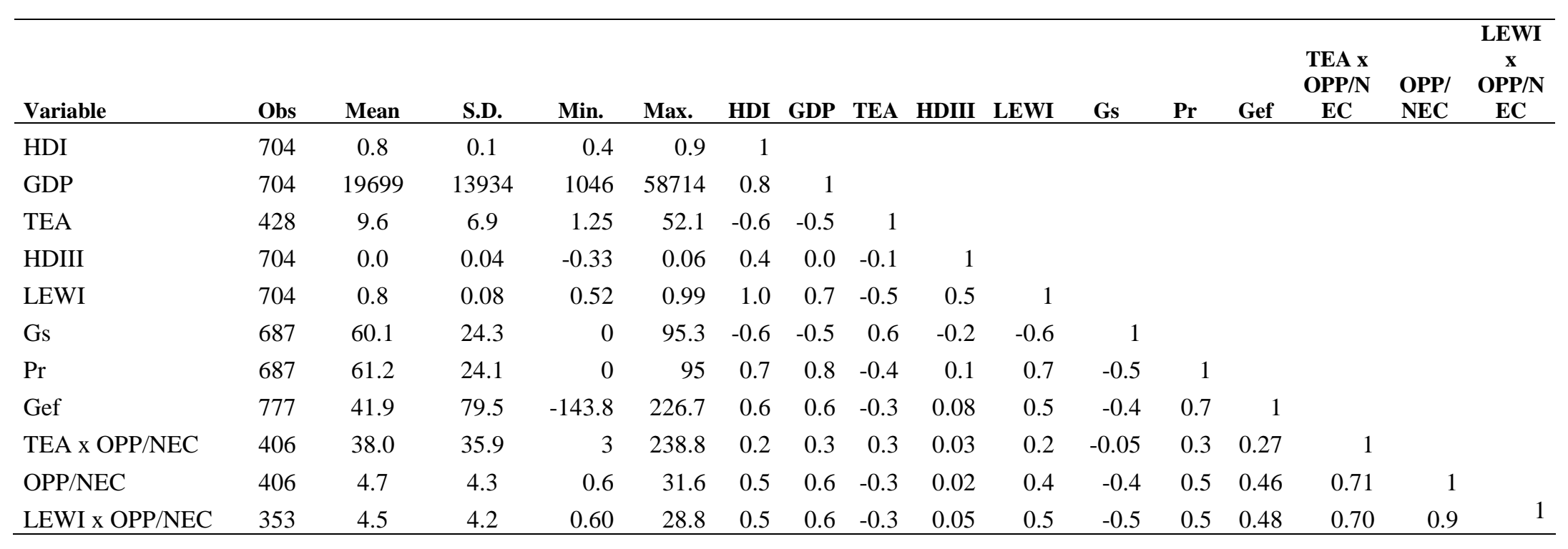


Table 3: Estimates of the parameters of the equations of HDIII, LEWI, GDP and OPP/NEC

\begin{tabular}{|c|c|c|c|c|c|}
\hline & $\begin{array}{c}\text { Equation of } \\
\text { HDIII }\end{array}$ & $\begin{array}{c}\text { Equation of } \\
\text { LEWI }\end{array}$ & $\begin{array}{c}\text { Equation of } \\
\text { GDP }\end{array}$ & $\begin{array}{c}\text { Equation of } \\
\text { OPP/NEC }\end{array}$ & $\begin{array}{l}\text { Equation of } \\
\text { OPP/NEC }\end{array}$ \\
\hline TEA & $\begin{array}{c}0.004^{* * *} \\
(0.001)\end{array}$ & $\begin{array}{r}-0.02 * * * \\
(0.005)\end{array}$ & $\begin{array}{l}-1802^{*} \\
(1023)\end{array}$ & & \\
\hline $\mathrm{TEA}^{2}$ & & $\begin{array}{c}0.0003^{*} \\
(0.0001)\end{array}$ & $\begin{array}{r}-7.0 \\
(32.1)\end{array}$ & & \\
\hline TEAxOPP/NEC & $\begin{array}{c}-0.0008^{* *} \\
(0.0003)\end{array}$ & $\begin{array}{r}0.002 * * * \\
(0.0003)\end{array}$ & $\begin{array}{r}744 * * * \\
(145)\end{array}$ & & \\
\hline LEWI & $\begin{array}{l}0.3 * * * \\
(0.08)\end{array}$ & & & $\begin{array}{r}232 \\
(237)\end{array}$ & $\begin{array}{r}-307 * * \\
(133)\end{array}$ \\
\hline LEWI $^{2}$ & & & & $\begin{array}{r}-168 \\
(158)\end{array}$ & $\begin{array}{r}198 * * \\
(79)\end{array}$ \\
\hline LEWIxOPP/NEC & $\begin{array}{l}0.003 * \\
(0.002)\end{array}$ & & & & \\
\hline \multicolumn{6}{|l|}{ HDIII } \\
\hline $\begin{array}{l}\text { GDP } \\
\text { GDP }^{2}\end{array}$ & & & & $\begin{array}{r}0.0008^{*} \\
(0.0004) \\
-8.21 \mathrm{E}-09\end{array}$ & \\
\hline & & & & (5.83E-09) & \\
\hline Constant & $\begin{array}{r}-0.3 * * * \\
(0.07)\end{array}$ & $\begin{array}{r}0.9 * * * \\
(0.03)\end{array}$ & $\begin{array}{r}14560^{* * *} \\
(7317)\end{array}$ & $\begin{array}{r}-82 \\
(90)\end{array}$ & $\begin{array}{r}120 * * \\
(56)\end{array}$ \\
\hline $\begin{array}{l}\text { Number of } \\
\text { countries }\end{array}$ & 64 & 64 & 64 & 64 & 64 \\
\hline $\begin{array}{l}N \\
\text { Kleibergen-Paap }\end{array}$ & 328 & 328 & 328 & 328 & 328 \\
\hline $\begin{array}{l}\text { Rank test } \\
\text { Chi-squared }\end{array}$ & 9.8 & 12.8 & 11.1 & 18.2 & 5.3 \\
\hline $\begin{array}{l}P \text {-value } \\
\text { Hansen }\end{array}$ & 0.08 & 0.05 & 0.05 & 0.003 & 0.07 \\
\hline $\begin{array}{l}J^{\prime} \text { Statistic } \\
\text { Chi-squared }\end{array}$ & 2.1 & 5.6 & 3.8 & 4.5 & 2.8 \\
\hline$P$-value & 0.7 & 0.3 & 0.4 & 0.3 & 0.1 \\
\hline $\begin{array}{l}\text { Instrumented } \\
\text { regressors }\end{array}$ & $\begin{array}{r}\text { TEA, TEAx } \\
\text { OPP/NEC } \\
\text { LEWIx } \\
\text { OPP/NEC }\end{array}$ & $\begin{array}{r}\text { TEA, TEAx } \\
\text { OPP/NEC }\end{array}$ & $\begin{array}{r}\text { TEA, } \\
\text { TEAx } \\
\text { OPP/NEC }\end{array}$ & LEWI, GDP & LEWI \\
\hline $\begin{array}{l}\text { Included } \\
\text { instruments }\end{array}$ & LEWI & $\mathrm{TEA}^{2}$ & $\mathrm{TEA}^{2}$ & $\mathrm{GDP}^{2}, \mathrm{LEWI}^{2}$ & $\mathrm{LEWI}^{2}$ \\
\hline $\begin{array}{l}\text { Excluded } \\
\text { Instruments }\end{array}$ & $\begin{array}{r}\text { Pr, Gs, Gef, } \\
\operatorname{Pr}^{2}, \mathrm{Gef}^{2}, \mathrm{Gs}^{2}, \\
\text { Gef } \mathrm{x} \text { Gs }\end{array}$ & $\begin{array}{r}\text { Pr, Gs, Gef, } \mathrm{Pr}^{2}, \\
\mathrm{Gef}^{2}, \mathrm{Gs}^{2}, \mathrm{Gef} \mathrm{x} \\
\mathrm{Pr}\end{array}$ & $\begin{array}{l}\text { Gs, Gef, } \mathrm{Pr}, \\
\mathrm{Gs}^{2}, \mathrm{Gef}^{2}, \mathrm{Pr}^{2}\end{array}$ & $\begin{array}{r}\text { Pr, Gs, Gef, } \mathrm{Pr}^{2} \\
\mathrm{Gef}^{2}, \mathrm{Gs}^{2}\end{array}$ & Pr, $\operatorname{Pr}^{2}$ \\
\hline
\end{tabular}

Standard errors between brackets. ***,**,* indicate statistically significant at 1\%, 5\% and 10\% respectively. 
Annex: List of GEM countries 2001-2010

$\begin{array}{llll}\text { Algeria } & \text { Germany } & \text { Mexico } & \text { Switzerland } \\ \text { Angola } & \text { Ghana } & \text { Montenegro } & \text { Syria } \\ \text { Argentina } & \text { Greece } & \text { Morocco } & \text { Taiwan } \\ \text { Australia } & \text { Guatemala } & \text { Netherlands } & \text { Thailand } \\ \text { Austria } & \text { Hong Kong } & \text { New Zealand } & \text { Tonga } \\ \text { Belgium } & \text { Hungary } & \text { Norway } & \text { Trinidad and Tobago } \\ \text { Bolivia } & \text { Iceland } & \text { Pakistan } & \text { Tunisia } \\ \text { Bosnia \& Herzegovina } & \text { India } & \text { Panama } & \text { Turkey } \\ \text { Brazil } & \text { Indonesia } & \text { Peru } & \text { Uganda } \\ \text { Canada } & \text { Iran } & \text { Philippines } & \text { United Arab Emirates } \\ \text { Chile } & \text { Ireland } & \text { Poland } & \text { United Kingdom } \\ \text { China } & \text { Israel } & \text { Portugal } & \text { United States } \\ \text { Colombia } & \text { Italy } & \text { Puerto Rico } & \text { Uruguay } \\ \text { Costa Rica } & \text { Jamaica } & \text { Romania } & \text { Vanuatu } \\ \text { Croatia } & \text { Japan } & \text { Russia } & \text { Venezuela } \\ \text { Czech Republic } & \text { Jordan } & \text { Saudi Arabia } & \text { West Bank \& Gaza Strip } \\ \text { Denmark } & \text { Kazakhstan } & \text { Serbia } & \text { Yemen } \\ \text { Dominican Republic } & \text { Korea } & \text { Singapore } & \text { Zambia } \\ \text { Ecuador } & \text { Latvia } & \text { Slovenia } & \\ \text { Egypt } & \text { Lebanon } & \text { South Africa } & \\ \text { Finland } & \text { Macedonia } & \text { Spain } & \\ \text { France } & \text { Malaysia } & \text { Sweden } & \end{array}$

